\title{
cand \\ Chemical Characterization and Anti-Inflammatory Activity of Phytoconstituents from Swertia alata
}

\author{
Sakshi Bajaj ${ }^{1}$, Shivkanya Fuloria ${ }^{2, *}$, Vetriselvan Subramaniyan ${ }^{3} \mathbb{D}$, Dhanalekshmi Unnikrishnan Meenakshi ${ }^{4}$, \\ Sharad Wakode ${ }^{1}$, Avneet Kaur ${ }^{5}$, Himangini Bansal ${ }^{1}$, Satish Manchanda ${ }^{1}$, Sachin Kumar ${ }^{1}$ \\ and Neeraj Kumar Fuloria ${ }^{2, *}$
}

check for

updates

Citation: Bajaj, S.; Fuloria, S.; Subramaniyan, V.; Meenakshi, D.U.; Wakode, S.; Kaur, A.; Bansal, H.; Manchanda, S.; Kumar, S.; Fuloria, N.K. Chemical Characterization and Anti-Inflammatory Activity of Phytoconstituents from Swertia alata. Plants 2021, 10, 1109. https:// doi.org/10.3390/plants10061109

Academic Editors: Stefania Lamponi and Sebastian Granica

Received: 3 April 2021

Accepted: 28 May 2021

Published: 31 May 2021

Publisher's Note: MDPI stays neutral with regard to jurisdictional claims in published maps and institutional affiliations.

Copyright: (c) 2021 by the authors. Licensee MDPI, Basel, Switzerland. This article is an open access article distributed under the terms and conditions of the Creative Commons Attribution (CC BY) license (https:/ / creativecommons.org/licenses/by/ $4.0 /)$.
1 Delhi Institute of Pharmaceutical Science and Research, Pushp Vihar, New Delhi 110017, India; sakshibajaj84@gmail.com (S.B.); sharadwakode@gmail.com (S.W.); himanginibansal@gmail.com (H.B.); manchandasatish@gmail.com (S.M.); s1378n@gmail.com (S.K.)

2 Faculty of Pharmacy, AIMST University, Kedah 08100, Malaysia

3 Faculty of Medicine, Bioscience and Nursing, MAHSA University, Kuala Lumpur 42610, Malaysia; drvetriselvan@mahsa.edu.my

4 College of Pharmacy, National University of Science and Technology, Muscat 130, Oman; dhanalekshmi@nu.edu.om

5 SGT College of Pharmacy, SGT University, Budhera, Gurugram 122505, India; avneetkaur1986@gmail.com

* Correspondence: shivkanya_fuloria@aimst.edu.my (S.F.); neerajkumar@aimst.edu.my (N.K.F.); Tel.: +60-143-034-057 (S.F.); +60-164-037-685 (N.K.F.)

\begin{abstract}
Swertia alata C.B Clarke (Gentianaceae) is a well-reported plant in the traditional system of medicine. The present study was intended to isolate the phytoconstituents from the ethanolic extract of the aerial parts of S. alata; and evaluate for in vitro COX-1/COX-2 inhibition activity, in vivo anti-inflammatory and ulcerogenic activity. Phytoisolation involved partitioning of S. alata ethanolic extract into petroleum ether and chloroform soluble fractions using silica gel-based column chromatography. The isolation afforded two phytoisolates, namely oleanolic acid (SA-1) and 3hydroxylup-12-(13)-ene-17-carboxylic acid (SA-4). Phytoisolates structures were established by melting point, ultraviolet (UV), attenuated total reflection-Fourier-transform infrared (ATR-FTIR), nuclear magnetic resonance (1H-NMR, 13C-NMR and HMBC) and mass spectrometry. Phytoisolates were further evaluated for in vitro cyclooxygenase (COX-1/COX-2) inhibitory activity, in vivo antiinflammatory and ulcerogenic activity. The study revealed SA-4 (COX-1/COX-2 inhibition activity of $104 / 61.68 \mu \mathrm{M}$ with $\%$ inhibition of 61.36 ) to be more effective than SA-1 (COX-1/COX-2 inhibition activity of $128.4 / 87.25 \mu \mathrm{M}$, with $\%$ inhibition of 47.72). SA-1 and SA-4, when subjected to ulcerogenic study, exhibited significant gastric tolerance. The current study reports chromatographic isolation and spectrometric characterization of SA-1 and SA-4. The present study concludes that compound SA-4 possess significant anti-inflammatory activity and less irritant property over gastric mucosa with no significant ulcerogenicity in comparison to indomethacin.
\end{abstract}

Keywords: Swertia alata; partitioned; chromatography; spectrometry; anti-inflammatory; ulcerogenic

\section{Introduction}

Swertia alata C.B Clarke (Gentianaceae) is a perennial herb and widely distributed plant in the west and north-west Himalayas, particularly in Kashmir to Kumaon, Mussorie, Dehradun, and the Nainital region of India [1]. Numerous species of Swertia are being used as substituents or adulterants of S. chirata. S. alata is used and unknowingly collected as $S$. chirata by traders for the preparation of several ayurvedic drugs [2]. S. alata is widely used in indigenous medicine as it possesses various properties. The bitterness, anthelmintic, hypoglycemic, and antipyretic properties are attributed to amarogentin, swerchirin, swertiamarin, and other active principles of the herb [3]. The most potential specie of Swertia genus is S. chirata, which is now nearly extinct from India. S. alata is 
known to possess oleanolic acid [4], swertisin [4], swertiamarin [5], swertianin, [6] methyl swertianin [6], methylbellidifolin [6], bellidifollin [7] swertiaperennine, and decussatin [8] but still very limited data is available over of the phytochemistry of $S$. alata. Non-steroidal anti-inflammatory drugs (NSAIDs) are among the most widely utilized medications in the world due to their efficacy in reducing pain and inflammation [9]. Inflammation is a typical defensive response to tissue injury, which includes a complex array of enzyme activation, mediator release, fluid extravasations, cell migration, tissue breakdown, and repair [10]. Inflammatory injuries actuate the release of a variety of systemic mediators, cytokines, and chemokines, which increases the rate of synthesis of prostaglandin [11]. Its production relies upon the activity of prostaglandin G/H synthases, colloquially known as COXs, bifunctional enzymes that contain both cyclooxygenase and peroxidase activity, which exist in two distinct isoforms, namely COX-1 and COX-2 [12]. The essential method of activity is inhibition of the pro-inflammatory enzyme cyclooxygenase (COX). NSAIDs as a class also involves the traditional nonselective NSAIDs (tNSAIDs) that nonspecifically repress both COX-1 and COX-2, and selectively inhibits COX-2. Albeit effective at relieving pain and inflammation, tNSAIDs are related with a significant risk of serious gastrointestinal adverse effects [13]. To overcome these adverse effects, specific inhibitors of the COX-2 isoenzyme were created, which opens the possibility to provide anti-inflammatory and analgesic advantages while hypothetically leaving the gastro protective activity of the COX1 isoenzyme in place. However, vital concerns have recently been raised with respect to the potential cardiovascular toxicity of COX-2 inhibitors [14]. Looking for selective COX-2 inhibitors without affecting the normal physiological functions of COX-1 has remained a noteworthy thrust area of anti-inflammatory pharmaceutical research. Nevertheless, the anti-inflammatory agents with greater activity towards COX-2 yet less receptive activity towards COX-1 are acknowledged as novel anti-inflammatory agents in the mainstream of anti-inflammatory research [15]. Due to the inherent problems associated with the current non- steroidal as well as steroidal anti-inflammatory agents, there is a continuous search for phytoconstituents having anti-inflammatory activity with reduced gastrointestinal side effects. Evidence suggests that in the past, Bajaj et al. isolated nonacosyl triacontanoate and 8-O-b-D-glucopyranosyl-(2-acetyl)-1,3-dihydroxy-5-methoxy-xanthone in S. alata plant and evaluated for in vitro COX-1/2, in vivo anti-inflammatory and ulcerogenic activity. The study revealed the significant anti-inflammatory potential of the isolates [16]. Based on the afore mentioned investigations, the present study was designed to further explore the presence of any new phytoisolate in the aerial parts of $S$. alata plant as a potential anti-inflammatory agent.

\section{Results}

The partitioning of S. alata ethanolic extract into petroleum ether and chloroform soluble fractions using silica gel-based column chromatography offered two phytoisolates: SA-1 and SA-4. The structural elucidations of isolated compounds were achieved by melting point, ultraviolet (UV), attenuated total reflection-Fourier-transform infrared (ATR-FTIR), nuclear magnetic resonance (1H-NMR, 13C-NMR and HMBC), and mass spectrometry.

\subsection{Structure Elucidation of Compounds}

\subsubsection{Oleanolic Acid (SA-1)}

The phyotoisolate SA-1 (Figure 1a) was obtained as white amorphous powder from elution of the column with chloroform: petroleum ether (2:8), $50 \mathrm{mg}(0.016 \%)$, and having a melting point of $71^{\circ} \mathrm{C}$.

The SA-1 exhibited ATR-FTIR $\left(\mathrm{cm}^{-1}\right)$ bands at $2917,2849,1730,726 ;{ }^{1} \mathrm{H}$ NMR and ${ }^{13} \mathrm{C}$ NMR signals (data given in Table 1); ESI-MS signals at $m / z: 457[\mathrm{M}+\mathrm{H}]^{+}$and $456[\mathrm{M}]^{+}$; and HMBC interaction (Figure 2a). 




(a)

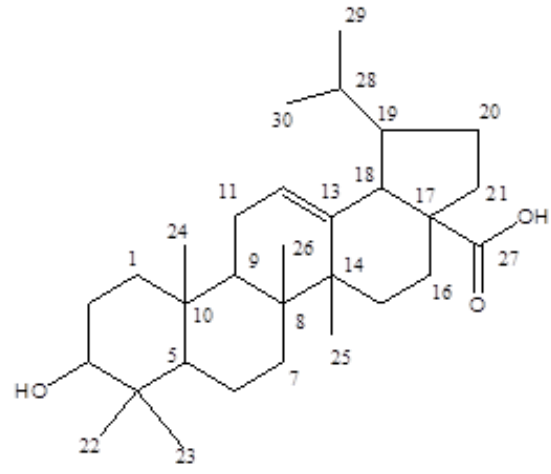

(b)

Figure 1. The chemical structures of (a) SA-1; and (b) SA-4.

Table 1. ${ }^{1} \mathrm{HNMR}$ and ${ }^{13} \mathrm{CNMR}$ data for compound SA-1.

\begin{tabular}{ccc}
\hline Position & ${ }^{\mathbf{1}} \mathbf{H}$ NMR & ${ }^{\mathbf{3}} \mathbf{C}$ NMR \\
\hline 1 & $1.18, \mathrm{~m}, 2 \mathrm{H}$ & 29.26 \\
2 & $1.79, \mathrm{~m}, 2 \mathrm{H}$ & 29.61 \\
3 & $3.56, \mathrm{~m}, 1 \mathrm{H}$ & 29.38 \\
4 & - & 77.02 \\
5 & $1.18, \mathrm{~m}, 1 \mathrm{H}$ & 29.26 \\
6 & $1.42, \mathrm{~m}, 2 \mathrm{H}$ & 29.38 \\
7 & $1.18, \mathrm{t}, 2 \mathrm{H}(J=7.22)$ & 29.26 \\
8 & - & 33.75 \\
9 & $2.13, \mathrm{t}, 1 \mathrm{H}(J=7.19)$ & 35.24 \\
10 & - & 29.61 \\
11 & $2.30, \mathrm{~d}, 2 \mathrm{H}(J=7.19)$ & 35.32 \\
12 & $5.21, \mathrm{t}, 1 \mathrm{H}(J=15.12)$ & 125.77 \\
13 & - & 127.28 \\
14 & - & 35.46 \\
15 & $1.89, \mathrm{t}, 2 \mathrm{H}(J=7.26)$ & 29.61 \\
16 & $2.5, \mathrm{t}, 2 \mathrm{H}(J=7.26)$ & 24.71 \\
17 & - & 35.52 \\
18 & $2.27, \mathrm{t}, 1 \mathrm{H}(J=7.12)$ & 35.62 \\
19 & $1.18, \mathrm{t}, 2 \mathrm{H}(J=7.12)$ & 29.26 \\
20 & - & 31.94 \\
21 & $1.18, \mathrm{~m}, 2 \mathrm{H}$ & 29.26 \\
22 & $2.13, \mathrm{t}, 2 \mathrm{H}(J=7.25)$ & 23.76 \\
23 & $0.4, \mathrm{~s}, 3 \mathrm{H}$ & 14.1 \\
24 & $0.45, \mathrm{~s}, 3 \mathrm{H}$ & 14.1 \\
25 & $0.52, \mathrm{~s}, 3 \mathrm{H}$ & 22.71 \\
26 & $0.78, \mathrm{~s}, 3 \mathrm{H}$ & 29.06 \\
27 & $0.81, \mathrm{~s}, 3 \mathrm{H}$ & 29.06 \\
28 & - & 178.33 \\
29 & $0.47, \mathrm{~s}, 3 \mathrm{H}$ & 24.71 \\
30 & $0.47, \mathrm{~s}, 3 \mathrm{H}$ & 24.71 \\
\hline
\end{tabular}

Note: Coupling constants in Hertz are provided in parenthesis.

\subsubsection{3-Hydroxylup-12-(13)-ene-17-carboxylic Acid (SA-4)}

The phyotoisolate SA-4 (Figure $1 \mathrm{~b}$ ) was obtained as yellow amorphous powder from elution of the column with chloroform: petroleum ether (3:7), $86 \mathrm{mg}(0.071 \%)$, and having a melting point of $110^{\circ} \mathrm{C}$. The SA-4 exhibited ATR-FTIR $\left(\mathrm{cm}^{-1}\right)$ bands at $2917,2849,1730$, 724; ${ }^{1} \mathrm{H}$ NMR and ${ }^{13} \mathrm{C}$ NMR signals (data given in Table 2); ESI-MS signals at $m / z 456$ [M] ${ }^{+}$ and $455[\mathrm{M}-\mathrm{H}]^{+}$); and HMBC interaction (Figure $2 \mathrm{~b}$ ). 


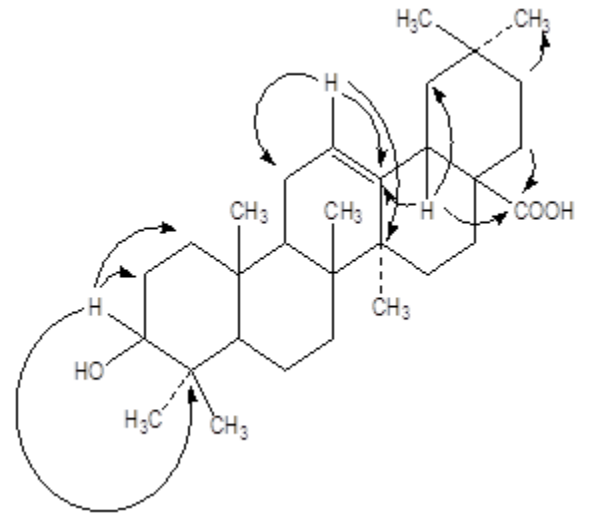

(a)



(b)

Figure 2. HMBC interaction in (a) SA-1 (b) SA-4.

Table 2. ${ }^{1} \mathrm{HNMR}$ and ${ }^{13} \mathrm{CNMR}$ data of compound SA-4.

\begin{tabular}{|c|c|c|}
\hline Position & ${ }^{1} \mathrm{H}$ NMR & ${ }^{13} \mathrm{CNMR}$ \\
\hline 1 & $1.18, \mathrm{~m}, 2 \mathrm{H}$ & 27.2 \\
\hline 2 & $1.70, \mathrm{~m}, 2 \mathrm{H}$ & 27.96 \\
\hline 3 & $3.72, \mathrm{~m}, 1 \mathrm{H}$ & 72.53 \\
\hline 4 & - & 27.82 \\
\hline 5 & $1.18, \mathrm{~m}, 1 \mathrm{H}$ & 27.2 \\
\hline 6 & $1.45, \mathrm{~m}, 2 \mathrm{H}$ & 27.82 \\
\hline 7 & $1.18, \mathrm{~m}, 2 \mathrm{H}$ & 27.2 \\
\hline 8 & - & 33.25 \\
\hline 9 & $1.18, \mathrm{~m}, 1 \mathrm{H}$ & 35.28 \\
\hline 10 & - & 27.96 \\
\hline 11 & $2.13, \mathrm{t}, 2 \mathrm{H}(J=7.6)$ & 35.32 \\
\hline 12 & $5.20, \mathrm{t}, 1 \mathrm{H}(J=15.1)$ & 125.42 \\
\hline 13 & - & 127.35 \\
\hline 14 & - & 35.46 \\
\hline 15 & $1.18, \mathrm{~m}, 2 \mathrm{H}$ & 27.96 \\
\hline 16 & $1.70, \mathrm{~m}, 2 \mathrm{H}$ & 24.97 \\
\hline 17 & - & 35.52 \\
\hline 18 & $2.23, \mathrm{~d}, 1 \mathrm{H}(J=7.2)$ & 35.62 \\
\hline 19 & $1.56, \mathrm{~m}, 1 \mathrm{H}$ & 51.63 \\
\hline 20 & $1.90, \mathrm{~d} 2 \mathrm{H},(J=12.2)$ & 35.62 \\
\hline 21 & $1.96, \mathrm{~d}, 2 \mathrm{H},(J=12.2)$ & 35.92 \\
\hline 22 & $0.81, \mathrm{~s}, 3 \mathrm{H}$ & 17.97 \\
\hline 23 & $0.85, \mathrm{~s}, 3 \mathrm{H}$ & 17.97 \\
\hline 24 & $0.95, \mathrm{~m}, 3 \mathrm{H}$ & 24.97 \\
\hline 25 & $0.95, \mathrm{~m}, 3 \mathrm{H}$ & 18.01 \\
\hline 26 & $0.95, \mathrm{~m}, 3 \mathrm{H}$ & 27.2 \\
\hline 27 & - & 27.2 \\
\hline 28 & $1.56, \mathrm{~m}, 1 \mathrm{H}$ & \\
\hline 29 & $0.65, \mathrm{~d}, 3 \mathrm{H}(J=7.22)$ & 17.97 \\
\hline 30 & $0.65, \mathrm{~d}, 3 \mathrm{H}(J=7.22)$ & 17.97 \\
\hline
\end{tabular}

Note: Coupling constants in Hertz are provided in parenthesis.

\subsection{Biological Activity}

2.2.1. In Vitro COX-1 and COX-2 Inhibitory Assay

The inhibitory activity of isolated compounds (SA-1 and SA-4) was evaluated against ovine COX-1 and human recombinant COX-2 (using enzyme immunoassay kit) to determine $\mathrm{IC}_{50}(\mu \mathrm{M})$ values (Table 3$)$. 
Table 3. $\mathrm{IC}_{50}$ of the synthesized compounds by in vitro COX-1 and COX-2 enzymatic assay and COX-2.

\begin{tabular}{ccc}
\hline Position & IC $_{\mathbf{5 0}}(\mu \mathrm{M})$ \\
& COX-1 & COX-2 \\
\hline SA-1 & 128.4 & 87.25 \\
SA-4 & 104 & 61.68 \\
Indomethacin & 53 & 36.56 \\
\hline
\end{tabular}

Note: $C_{50}$ value is the concentration of the compound required to produce $50 \%$ of inhibition of COX-1 and COX-2 respectively using enzyme immuno-assay kit (Catalog No. 560131, Cayman Chemicals, Inc., Ann Arbor, MI, USA).

\subsubsection{In Vivo Anti-Inflammatory Activity}

The degree of swelling of the carrageenan injected paws was maximal at the third hour after injection. Statistical analysis revealed that SA-4 $(8 \mathrm{mg} / \mathrm{kg})$ significantly inhibited the development of edema at the third hour after treatment $(p<0.05)$. The biological data for SA-1 and SA-4 is shown in Table 4, which clearly implies that the isolated compounds exhibited varying degree of anti-inflammatory activity.

Table 4. In vivo anti-inflammatory activity of compounds using carrageenan-induced rat paw edema method.

\begin{tabular}{crc}
\hline \multicolumn{2}{c}{ Compound } & $\begin{array}{c}\text { Increase in Paw Edema }(\mathbf{m L})^{\mathbf{a}, \mathbf{b}} \\
(\text { Mean } \pm \text { SEM) }\end{array}$ \\
\hline \multirow{3}{*}{$\mathrm{SA}-1$} & $2 \mathrm{mg} / \mathrm{kg}$ & $0.29 \pm 0.00$ \\
& $4 \mathrm{mg} / \mathrm{kg}$ & $0.27 \pm 0.22$ \\
& $8 \mathrm{mg} / \mathrm{kg}$ & $0.23 \pm 0.01$ \\
$\mathrm{SA}-4$ & $2 \mathrm{mg} / \mathrm{kg}$ & $0.28 \pm 0.00$ \\
& $4 \mathrm{mg} / \mathrm{kg}$ & $0.26 \pm 0.22$ \\
& $8 \mathrm{mg} / \mathrm{kg}$ & $0.17 \pm 0.01$ \\
& Control & $0.44 \pm 0.04$ \\
\multicolumn{2}{c}{ Indomethacin } & $0.15 \pm 0.02$
\end{tabular}

Note: $p$-values were compared with the control group ( $3 \mathrm{~h}$ after inducing edema) (Tukey's test). Number of animals (rats) in each group $=5$. ${ }^{\text {a }}$ Values are determined after $3 \mathrm{~h}$ and are expressed as Mean \pm SEM. ${ }^{\mathrm{b}} p<0.05$ (significant difference).

\subsubsection{Ulcerogenic Activity}

The results presented in Table 5 reveals compound SA- 1 and SA- 4 to possess a better gastrointestinal safety profile with an ulcer score of $2.5 \pm 0.61$ and $1.8 \pm 0.44$, respectively, in comparison to the standard drug Indomethacin $2.7 \pm 0.273$. Further, SA-4 possesses significantly less ulcerogenic potential as compared with SA- 1 in a dose of $12 \mathrm{mg} / \mathrm{kg}$. The macroscopic view to support ulcerogenic activity of compound SA-1 and SA-4 is also presented in the Figure 3.

Table 5. In vivo ulcerogenic activity of the compounds in rat model.

\begin{tabular}{|c|c|c|}
\hline \multicolumn{2}{|c|}{ Compound } & \multirow{2}{*}{$\begin{array}{c}\begin{array}{c}\text { Ulcerogenic Activity }^{\mathbf{a}} \\
\text { (Severity Index) }^{\mathbf{b}, \mathbf{c}} \\
\text { (Mean } \pm \text { SD) }\end{array} \\
0.0 \pm 0.00\end{array}$} \\
\hline & $6 \mathrm{mg} / \mathrm{kg}$ & \\
\hline \multirow[t]{3}{*}{ SA-1 } & $12 \mathrm{mg} / \mathrm{kg}$ & $0.0 \pm 0.00$ \\
\hline & $24 \mathrm{mg} / \mathrm{kg}$ & $2.5 \pm 0.61$ \\
\hline & $6 \mathrm{mg} / \mathrm{kg}$ & $0.0 \pm 0.00$ \\
\hline \multirow[t]{2}{*}{ SA-4 } & $12 \mathrm{mg} / \mathrm{kg}$ & $1.8 \pm 0.44$ \\
\hline & $24 \mathrm{mg} / \mathrm{kg}$ & $2.1 \pm 0.44$ \\
\hline \multirow{2}{*}{\multicolumn{2}{|c|}{$\begin{array}{c}\text { Control } \\
\text { Indomethacin }\end{array}$}} & $0.0 \pm 0.00$ \\
\hline & & $2.7 \pm 0.27$ \\
\hline
\end{tabular}

Note: ${ }^{\text {a }}$ Number of animals in each group is $5 .{ }^{b}$ Severity Index $=$ mean score of treated group and mean score of control group. ${ }^{\mathrm{c}} p<0.5$ (significant difference). 



Figure 3. Macroscopic observation of gastric mucosal lesions in the ulcer model; (a) Indomethacin (21 mg/kg); (b) control; (c) SA-4 (12 mg/Kg); (d) SA-4 (24 mg/kg); (e) SA-1 (24 mg/Kg).

\section{Discussion}

\subsection{Isolation of Phytoconstituents}

The current study intended to explore any new phytoisolate present in the aerial parts of $S$. alata plant. For this purpose, $50 \mathrm{~g}$ of prepared extract of $S$. alata was successively eluted with chloroform and petroleum ether using normal phase column chromatography. This yielded 16 fractions (each fraction of $400 \mathrm{~mL}$ ) using eluent system of chloroform: petroleum ether in different ratio in various fractions, such as: F1-5 (1.5:8.5), F6-10 (1.6:8.4), F11-15 (1.7:8.3), F16-20 (1.8:8.2), F21-25 (1.9:8.1), F26-30 (2:8), F31-35 (2.1:7.9), F36-40 (2.2:7.8), F41-45 (2.3:7.7), F46-50 (2.4:7.6), F51-55 (2.5:7.5), F56-60 (2.6:7.4), F61-65 (2.7:7.3), F66-70 (2.8:7.2), F71-75 (2.9:7.1), and F76-80 (2:8). The fractions 26-30, when combined and exposed to TLC, offered a new spot with Rf value of 0.49 (chloroform:methanol, 3:2). The fraction $26-30$, when dried and subjected to purification by preparative TLC, offered pure white amorphus mass SA-1. Whereas, the fractions 76-80 when combined and exposed to TLC, offered a new spot with Rf value of 0.53 (chloroform:methanol, 4:1). The fraction 76-80, when dried and subjected to purification by preparative TLC, offered pure yellow amorphus mass SA-4. The flow chart given in Figure 4, presents the extraction and isolation of phytoisolates from S. alata plant using various fractions.

\subsection{Characterization of Phyto-Isolates}

The compound SA-1, identified as oleanolic acid, was obtained as white amorphous powder. It was acid hydrolysed and responded positively to the Liebermann-Burchard test for steroids. The presence of sterol nucleus was confirmed by acid hydrolysis using $2 \mathrm{M} \mathrm{H}_{2} \mathrm{SO}_{4}$. The IR spectrum showed the characteristic absorption bands at $(2917,2849)$ for $\mathrm{C}-\mathrm{H}$ stretching, and (1730) for $\mathrm{C}=\mathrm{O}$ stretching and thereby confirmed the presence of the carbonyl group. The generation of the prominent ion peaks at $m / z 457\left[\mathrm{C}_{30} \mathrm{H}_{48} \mathrm{O}_{3}\right]^{+}$ was attributed to the molecular ion of oleanolic acid. Other fragment ions peaks at $m / z 439$ $\left[\mathrm{C}_{30} \mathrm{H}_{47} \mathrm{O}_{2}\right]^{+}, 411\left[\mathrm{C}_{29} \mathrm{H}_{47} \mathrm{O}\right]^{+}, 395\left[\mathrm{C}_{29} \mathrm{H}_{47}\right]^{+}, 248\left[\mathrm{C}_{16} \mathrm{H}_{24} \mathrm{O}_{2}\right]^{+}, 235\left[\mathrm{C}_{15} \mathrm{H}_{24} \mathrm{O}_{2}\right]^{+}$supported the presence of steroidal structure. 


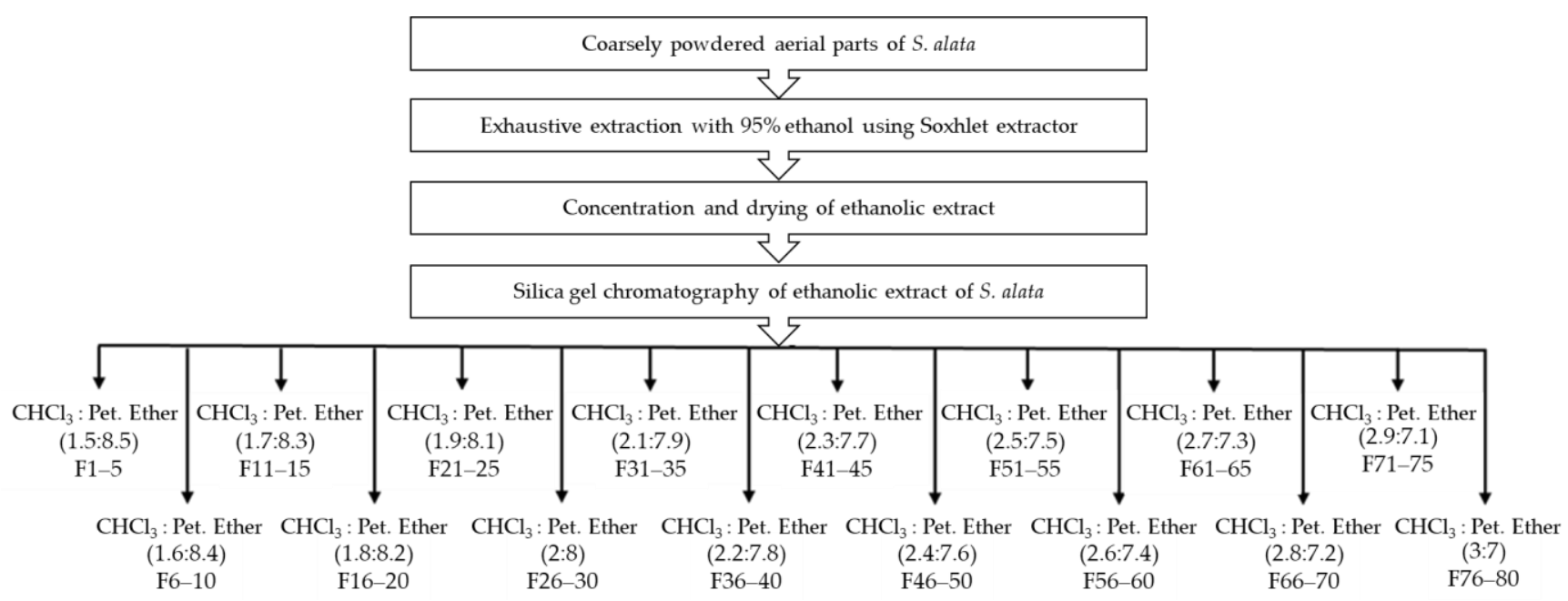

Figure 4. Flowchart representing the extraction and isolation of phytoisolates from S. alata extract using various fractions of chloroform and petoleum ether as eluent.

The ${ }^{1} \mathrm{H}$ NMR spectrum of compound SA-1, methyl protons displayed one singlet at $\delta 0.47$ for $6 \mathrm{H}$ assigned to $\mathrm{H}-29$ and $\mathrm{H}-30$ protons, two singlets at $\delta 0.4$ and 0.45 assigned to $\mathrm{H}-23$ and $\mathrm{H}-24$ protons, and three singlets at $\delta 0.52,0.78,0.81$ were assigned to $\mathrm{H} 25$, $\mathrm{H}-26$, and $\mathrm{H}-27$ protons, respectively. There was a characteristic triplet signal at $\delta 5.21$ with $J$ value of 15.12 assigned to $\mathrm{H}-12$. The protons of $\mathrm{OH}$ and $\mathrm{COOH}$ group displayed a characteristic broad signal at $\delta 12.42$ and 12.6, respectively. The remaining methylene and methine unit protons displayed broad multiplet signals between $\delta 0.47$ and 2.13. The ${ }^{13} \mathrm{C}$ NMR spectrum data of SA-1 exhibited important signals at $\delta 14.21$ for C-23 and C- 24, signal at $\delta 24.71$ for C-29 and C-30. The signal at $\delta 29.06$ was assigned to C-26 and C-27. A signal at $\delta 22.71$ was assigned to $C-25$, the signal at $\delta 32.02$ was assigned to $C-31$, and the signal at 178 was assigned to carbonyl carbon. The two characteristic signals at $\delta 125.77$ and 127.28 were assigned to $\mathrm{C} 12$ and $\mathrm{C} 13$, respectively. The carbonyl group signal appeared at $\delta$ 178.45. The remaining 19 carbons displayed their signals from $\delta 14.1$ to 77.02 (Table 1).

The HMBC correlations of $\mathrm{H}-\mathrm{C}(3)$ with $\mathrm{C}(1), \mathrm{C}(2), \mathrm{C}(4), \mathrm{C}(23)$, and $\mathrm{C}(24)$, of $\mathrm{H}-\mathrm{C}(9)$ with $\mathrm{C}(5), \mathrm{C}(8)$, and $\mathrm{C}(10)$, of $\mathrm{H}-\mathrm{C}(12)$ with $\mathrm{C}(11), \mathrm{C}(13), \mathrm{C}(14)$, and $\mathrm{C}(18)$, of $\mathrm{H}-\mathrm{C}(18)$ with $\mathrm{C}(13), \mathrm{C}(14), \mathrm{C}(16)$, and $\mathrm{C}(28)$, and of $\mathrm{H}-\mathrm{C}(22)$ with $\mathrm{C}(28)$, indicated the relative positions of these groups in the molecule SA-1 (Figure 2a).

The IR data, mass fragmentation pattern, ${ }^{1} \mathrm{H}$ NMR, and ${ }^{13} \mathrm{C}$ NMR chemical shifts of the isolated compound SA-1 were comparable with related compound viz, oleanolic acid. Based on spectral data analysis and acid hydrolysis based chemical identification, the structure of isolated compound SA-1 was finally elucidated as oleanolic acid.

The compound SA-4 identified as 3-hydroxylup-12-(13)-ene-17-carboxylic acid, was obtained as yellow amorphous powder. It was obtained chemically by acid hydrolysis. It responded positively to the Liebermann-Burchard test for steroids and formed effervescence with sodium bicarbonate solution, indicating the presence of carboxylic acid group in the molecule. The chemical identification was done by acid hydrolysis method using $2 \mathrm{M} \mathrm{H}_{2} \mathrm{SO}_{4}$, which confirmed the presence of sterol nucleus. The IR spectrum showed characteristic absorption bands for $(2917,2848)$ for $\mathrm{C}-\mathrm{H}$ stretching, and $(1735)$ for $\mathrm{C}=\mathrm{O}$ stretch to confirm the presence of carbonyl group. The +ve ion mass spectrum showed a molecular ion peak at $m / z 456\left[\mathrm{C}_{30} \mathrm{H}_{48} \mathrm{O}_{3}\right]^{+}$corresponding to $\mathrm{M}^{+}$ion, and $455\left[\mathrm{C}_{30} \mathrm{H}_{47} \mathrm{O}_{3}\right]^{+}$ corresponds to $\mathrm{M}-1$ peak, which indicated saturated nature of molecule. The characteristic signals at $m / z 439\left[\mathrm{C}_{30} \mathrm{H}_{47} \mathrm{O}_{2}\right]^{+}, 411\left[\mathrm{C}_{29} \mathrm{H}_{47} \mathrm{O}\right]^{+}, 395\left[\mathrm{C}_{29} \mathrm{H}_{47}\right]^{+}$, and $235\left[\mathrm{C}_{15} \mathrm{H}_{24} \mathrm{O}_{2}\right]^{+}$ suggested the presence of steroidal structure.

The ${ }^{1} \mathrm{H}-\mathrm{NMR}$ spectrum of compound SA-4, methyl protons displayed one singlet at $\delta 0.65$ for $6 \mathrm{H}$ assigned to $\mathrm{H}-29$ and $\mathrm{H}-30$, two singlets at $\delta 0.81$ and 0.85 assigned to $\mathrm{H}-22$ and $\mathrm{H}-23$ protons, respectively, and one singlet at $\delta 0.95$, which was assigned to $\mathrm{H} 24, \mathrm{H}-25$, 
and H-26 protons. There was a characteristic triplet signal at $\delta 5.20$ with $J$ value of $15.1 \mathrm{~Hz}$ assigned to $\mathrm{H}-12$. The protons of hydroxy and $\mathrm{COOH}$ group displayed characteristic broad signal at $\delta 12.49$ and 12.56, respectively. The remaining methylene and methine unit protons displayed broad multiplet signals at $\delta 0.95-3.72$. The ${ }^{13} \mathrm{C}$ NMR spectrum data of SA-4 exhibited important signals for two methyl carbons at $\delta 17.97$ C-22, C-23, C-29, and C-30. The signal at $\delta 27.2$ was assigned to C-26 and C-27. A signal at 18.01 was assigned to $\mathrm{C}-25$. The signal $\delta 178$ was assigned to carbonyl carbon. The two characteristic signals at $\delta$ 125.42 and 127.35 were assigned to $C 12$ and $C 13$, respectively. The remaining 19 carbons displayed their signals from $\delta 14.1$ to 72.53 (Table 2).

The HMBC correlations of $\mathrm{H}-\mathrm{C}(3)$ with $\mathrm{C}(1), \mathrm{C}(2), \mathrm{C}(4), \mathrm{C}(23)$, and $\mathrm{C}(24)$, of $\mathrm{H}-\mathrm{C}(9)$ with $C(5), C(8)$, and $C(10)$, of $\mathrm{H}-\mathrm{C}(12)$ with $\mathrm{C}(11), \mathrm{C}(13), \mathrm{C}(14)$, and $\mathrm{C}(18)$, of $\mathrm{H}-\mathrm{C}(18)$ with $C(13), C(14), C(16), C(19)$ and $C(27)$, and of $H-C(21)$ with $C(27)$, indicated the relative positions of these groups in the molecule SA-4 (Figure $2 b$ ).

The IR, data, mass fragmentation pattern, ${ }^{1} \mathrm{H}$ and ${ }^{13} \mathrm{C}$ NMR chemical shifts of the isolated compound SA-4 were comparable with related compound viz and hydroxylupic acid. Based on spectral data analysis and acid hydrolysis-based chemical identification, the structure of isolated compound SA-4, was finally elucidated as 3-hydroxylup-12-(13)-ene17-carboxylic acid. This is a new compound reported for the first time in S. alata species. The spectral characterization of molecular structure of isolated compounds SA-1 and SA-4 was confirmed and supported using standard literature [17-19].

\subsection{In Vitro COX-1 and COX-2 Inhibitory Assay}

COX-1 and COX-2 catalyze the biosynthesis of prostaglandin $\mathrm{H} 2$ from the arachidonic acid substrate. The inhibition of COX-1 results in some undesirable side-effects, whereas COX-2 inhibition provides therapeutic effects in pain, inflammation, cancer, glaucoma, and Alzheimer's and Parkinson disease [20]. COX-2 is an inducible enzyme, while COX-1 is constitutive, that is, present even in the absence of inflammatory conditions. In addition to the pro-inflammatory prostaglandins, COX-1 is responsible for the synthesis of those prostaglandins that are necessary for maintaining the integrity of gastro-intestinal mucosa. A higher inhibition of COX-1 increases the tendency of a drug to induce gastric ulcers and related complications [21].

The IC50 values of indomethacin for COX-1 and COX-2 were observed as $53.00 \mu \mathrm{M}$ and $36.56 \mu \mathrm{M}$, respectively. The results of the in vitro COX-1 and COX-2 inhibitory studies revealed that the isolated compounds SA-1 and SA-4 potentially inhibit COX-2 $\left(\mathrm{IC}_{50}=61.68-87.25 \mu \mathrm{M}\right.$ range $)$ over the COX-1 104-128 $\mu \mathrm{M}$ range, whereas isolated compound SA-4 (COX-1/COX-2 = 104/61.68) were found to be potent inhibitor of COX-2 than SA-1 (COX-1/COX-2 = 128.4/87.25). To understand the inhibitory activity of these isolated compounds, they are further evaluated for their in vivo anti-inflammatory activity.

\subsection{Anti-Inflammatory Activity}

Anti-inflammatory activity of the phytocompounds (SA-1 and SA-4) was evaluated as per the method of Winter et al. with minor modifications. Carageenan was used to induced paw Edema in Wistar albino rat. Carrageenan induced paw edema is a standard assay for acute inflammation that is effectively employed to evaluate the phytoisolate against anti-inflammatory activity [22,23]. Edema is produced by a sequential release of inflammatory mediators such as histamine, serotonin, kinnins, prostaglandins and bradykinins, which leads to fluid accumulation [24]. Edema is characteristic of an acute inflammatory response [25]. The release of histamine or serotonin occurs in the first phase (up to $1 \mathrm{~h}$ ) and the second phase (over $1 \mathrm{~h}$ ) is associated with the production of bradykinins [26]. It is well known that the third phase of the edema induced by carrageenan, in which the edema reaches its highest volume, is characterized by the presence of prostaglandins and other compounds of slow reaction $[27,28]$. Previous studies have shown that phytocompounds of $S$. alata play an important pharmacological role in inflammation [29]. In the present study, among the two phytoisolates of $S$. alata, the compound SA-4 $(24 \mathrm{mg} / \mathrm{kg})$ 
was found to be more effective than SA-1 via the inhibition of the COX-1/COX-2 pathway. Results of the present study revealed that the phytoisolates SA-1 and SA-4 exhibit dose-dependent anti-inflammatory activity by suppressing the rat paw edema. The potent suppressive effect of SA-1 and SA-4 on inflammatory mediators was exerted by blocking of the expression of COX enzymes at different doses $(2,4$, and $8 \mathrm{mg} / \mathrm{kg})$. Additionally, macroscopical examination suggests that $24 \mathrm{mg} / \mathrm{kg}$ of $S$. alata can be an effective treatment for the management of inflammatory responses. These results suggest that phytoisolate of SA-4 could be a potent action for the anti-inflammatory effects. Moreover, several studies support that $S$. alata species have shown antioxidative effects [30,31]. Inhibition of COX by $S$. alata leads to a decrease in all prostaglandin and thromboxane synthesis, which accounts for the beneficial anti-inflammatory and prevents ulcerogenic effects [32]. Epidemiological evidence has convincingly demonstrated, through the inhibition of COX enzymes, the reduction in cancer risk [33]. Based on the antioxidant effect, SA4 may involve the inhibition of cyclooxygenase/prostaglandin-endoperoxide synthase (PGHS-1 and PGHS-2), and regulatory enzymes, involved in the biosynthesis of prostaglandin (PG) which is strongly implicated in inflammation [34].

\subsection{Ulcerogenic Activity}

It has been reported that non-steroidal anti-inflammatory agents are inadequately dissolvable in gastric acid and stay in contact with the stomach wall for a more extended period, thus producing a highly dangerous local concentration. This leads to local irritation of the stomach wall followed by ulceration. This prompts to local irritation of the stomach wall after ulceration [35]. Both the compounds SA-1 and SA-4 possessing in vivo antiinflammatory activity were further screened for their ulcerogenic activity according to the Cioli method. The compounds SA- 1 and SA- 4 were administered to the animals via oral gavage $(6 \mathrm{mg} / \mathrm{kg}, 12 \mathrm{mg} / \mathrm{kg}$, and $24 \mathrm{mg} / \mathrm{kg})$. Moreover, the results of the current study expressed that the action on inhibition of the ulcerogenic effect depends on different doses of SA-1 and SA-4 $(6,12,24 \mathrm{mg} / \mathrm{kg})$. SA-4 at the dose of $24 \mathrm{mg} / \mathrm{kg}$ showed significant ulcerogenic potential compared to the control treated group at doses of 6 and $12 \mathrm{mg} / \mathrm{kg}$. Figure 3 presents the macroscopic view of effect of SA-1 and SA- 4 on gastric mucosal lesions in ulcer model. The standard drug of indomethacin dose was chosen based on the standard references, which used Indoimethacin up to $40 \mathrm{mg}[36,37]$. As per Table 4, the anti-inflammatory activity of compounds SA-1 and SA-4 (administered at doses from 2 to $8 \mathrm{mg} / \mathrm{kg}$ ) is comparable with Indomethacin (administered at the dose of $21 \mathrm{mg} / \mathrm{kg}$, po). Table 5 expressed that ulcerogenic activity of compounds SA-1 and SA-4 $(6-24 \mathrm{mg} / \mathrm{kg})$ is also comparable to high dose indomethacin $(21 \mathrm{mg} / \mathrm{kg})$. Several anti-inflammatory and antioxidants studies wherein indomethacin have been used as a standard to compare the anti-inflammatory activity of phytoisolates [38-40]. The present study was designed based on the standard studies, where a similar experimental design was used [41-44].

The present study intended to explore the new phytochemical entities in the aerial part of $S$. alata species and investigate their anti-inflammatory potential. Fortunately, the present study explored and isolated a new compound SA-4 (3-hydroxylup-12-(13)-ene17-carboxylic acid), which is reported for the first time in the S. alata species. Apart from that, this is the first time the anti-inflammatory potential of 3-hydroxylup-12-(13)-ene-17carboxylic acid has been explored in S. alata species. So, this research acclaims its edge and novelty over other studies on the $S$. alata plant. A strong correlation between the potency of NSAID's as an inhibitor of prostaglandin synthesis and ulcerogenic activity has been observed [45,46]. Most potent compound SA-4 showed a severity index lower than the standard drug Indomethacin. Hence, this compound may have better safety margin on gastric mucosa than indomethacin. 


\section{Materials and Methods}

\subsection{General}

The chemical and solvents used were purchased from commercial vendors and used without purification. The melting points of all isolates were determined in open capillary tube and were uncorrected. Ultraviolet spectra were recorded in methanol $(\mathrm{MeOH})$ on a Shimadzu UV-160A UV visible recording spectrophotometer (Shimadzu Scientific Instruments, Kyoto, Japan). IR spectra were recorded on Bruker ATR-FTIR spectrophotometer. Mass spectra were recorded using electron impact ionization at $70 \mathrm{eV}$ on an ESIMS analyst QTOF mass spectrometer (Agilent, Mississauga, ON, Canada). The ${ }^{1} \mathrm{H}-\mathrm{NMR},{ }^{13} \mathrm{C}-\mathrm{NMR}$, and HMBC spectra were taken on a Bruker-Advance III-010601AM-500 spectrometer (Bruker Corporation, Karlsruhe, Germany) in $\mathrm{CDCl}_{3}$ and $\mathrm{D}_{2} \mathrm{O}$ using TMS as an internal standard expressing coupling constants (J values) in Hertz (Hz). Silica gel G (Qualigen, 60-120 mesh) was used for column chromatography. TLC was performed on plates coated with silica gel G (Merck, Darmstadt, Germany).

\subsection{Plant Material and Extract Preparation}

The plant material was supplied by Almas Pharmaceutical Ltd., Uttar Pradesh, India and identified by Dr. H.B Singh, Scientist F and Head, Raw Material Herbarium and Museum, NISCAIR (National Institute of Science Communication and Information Resources) Pusa Gate, New Delhi. The voucher specimen (NISCAIR/RHMD/2013/2185/190) of the test drug has been deposited in the herbarium of NISCAIR, India for future reference. The aerial parts were carefully collected and air dried under shade. The air-dried materials were reduced to coarse powder. The coarse powdered material $(1.2 \mathrm{~kg})$ was subjected to exhaustive extraction with 95\% ethanol in a SOXHLET apparatus for $50 \mathrm{~h}$. The extract was concentrated in rotary evaporator to yield greenish brown color 52.63 gms (4.385\%) residue.

\subsection{Isolation and Purification}

The isolation of phytoisolates was based on the standard protocol with minor modification [47]. Briefly, the ethanolic extract $(50 \mathrm{~g})$ of $S$. alata was subjected to column chromatographic critical isolation by dissolving in the minimum volume of ethanol and adsorbed on the silica gel (60-120 mesh) slowly for preparation of a slurry. The extract was air-dried, powdered, and passed through a sieve (No. 8) to get uniform particle size. The clean and dried column plugged on the lower side with nonabsorbent cotton was fixed in a vertical position on the stand. After the column was half filled with petroleum ether, the silica gel (60-120 mesh) for column chromatography was poured in small portions and allowed to settle to form a stationary phase. The dried slurry of $S$. alata extract was loaded over the column and eluted successively with various combinations of chloroform: petroleum ether $(1.5: 8.5,1.6: 8.4,1.7: 8.3,1.8: 8.2,1.9: 8.1,2: 8,2.1: 7.9,2.2: 7.8,2.3: 7.7$, 2.4:7.6, 2.5:7.5, 2.6:7.4, 2.7:7.3, 2.8:7.2, 2.9:7.1, and 3:7). The collected fractions homogeneity was checked by thin layer chromatography (TLC). Fractions with same retention factor (Rf) values were combined and concentrated. The concentrate was purified by preparative TLC using suitable solvent system to offer the pure phytoisolates SA-1 and SA-4. The purified phytoisolates were subjected to ultraviolet (UV), attenuated total reflectionFourier-transform infrared (ATR-FTIR), nuclear magnetic resonance $\left(1 \mathrm{H}-\mathrm{NMR},{ }^{13} \mathrm{C}-\mathrm{NMR}\right.$ and $\mathrm{HMBC}$ ) and mass spectrometric studies for their structural elucidation.

\subsection{Animals}

The animals (Wistar albino rats) used in the study were procured from Animal House Center and were divided and housed in different cages at 25 to $28^{\circ} \mathrm{C}$, under well maintained hygienic and environmental conditions with a relative humidity of 50 to $65 \%$, under $12 \mathrm{~h}$ light and dark cycles. All animals were acclimatized for a week before use. All experimental work was conducted after receiving the approval from Institutional Animal Ethics Committee (IAEC) via protocol no. IAEC/2015-I/Prot no. 09, 10 and IAEC/2016I/Prot no. 10, Delhi Institute of Pharmaceutical Sciences and Research, New Delhi. 


\subsection{In Vitro Activity}

The isolated compounds were screened for their in vitro COX-1 and COX-2 enzymatic activity using an enzyme immunoassay kit (catalog No. 560131, Cayman Chemicals Inc., Ann Arbor, MI, USA). The enzymatic assay was performed as per the manufacturer's assay instructions and standard literature [48]. COX-1 and COX-2 enzymatic activity provides a simple, sensitive, and high-throughput adaptable method to detect the peroxidase activity of COX in biological samples or purified/crude enzyme preparations. The kit includes COX-1 and COX-2 specific inhibitors to differentiate the activity of COX-1 and COX-2 as well as other peroxidases, which may be present in the sample [49]. The efficiencies of the test compounds that cause $50 \%$ inhibition of COX-2 were calculated as IC50 from the concentration-response curve. The compounds were further tested for their in vivo anti-inflammatory activity. Our study showed the phytoisolate of SA-4 (COX-1/COX-2 inhibition activity of $104 / 61.68 \mu \mathrm{M}$ with $\%$ inhibition of 61.36 ) to be more effective than SA-1 (COX-1/COX-2 inhibition activity of $128.4 / 87.25 \mu \mathrm{M}$, with \% inhibition of 47.72 ).

\subsection{In Vivo Activity \\ 4.6.1. Anti-Inflammatory Activity}

The anti-inflammatory activity of isolated compound was evaluated on Wistar albino rat using carrageenan induced rat paw edema method as per the procedure described in earlier research [50]. The animals were divided into groups, consisting of five rats in each group. The prepared compounds were administered orally at doses of $2,4,8 \mathrm{mg} / \mathrm{kg}$ body weight (oral gavage) and the volume of paw was determined plethysmographically (Ugo-Basile, Gemonio (VA), Italy). The control group received the equivalent volume of normal saline and indomethacin $(8 \mathrm{mg} / \mathrm{kg}$ b.wt.) was administered orally to the reference group. Carrageenan $(0.1 \mathrm{~mL}, 1.0 \% w / v$ in $0.9 \%$ of normal saline) was injected after half an hour into the sub-plantar tissue of the rat's hind paw. The paw volume was measured at hourly intervals for $3 \mathrm{~h}(0,1,2$, and $3 \mathrm{~h})$ and the percent inhibition of edema was calculated using the following formula:

$$
\% \text { inhibition }=\left(1-\mathrm{V}_{\mathrm{s}} / \mathrm{V}_{\mathrm{c}} \times 100\right),
$$

where, $\mathrm{V}_{\mathrm{S}}=$ paw volume in sample treated group, $\mathrm{V}_{\mathrm{c}}=$ paw volume in control group.

\subsubsection{Acute Ulcerogenic Activity}

The ulcerogenic activity of the isolated compound was performed according to previous reported method [51]. Each study group consisted of five Wistar albino rats. The animals were fasted for $18 \mathrm{~h}$ before the administration of the test compound, while water was given continuously. The dose quantity was made three times $(6,12,24 \mathrm{mg} / \mathrm{kg})$ of the administered dose for anti-inflammatory studies $(2,4,8 \mathrm{mg} / \mathrm{kg})$. The control group received only normal saline. After $6 \mathrm{~h}$ of drug administration the rats were sacrificed, the stomach was removed and opened around the greater curvature. The inner lining was washed properly with distilled water followed by normal saline. The mucosal damage was examined, and the number of ulcers and severity index was calculated on a scale of 0 to 3 , where: $0=$ no lesions; $0.5=$ redness; $1.0=$ spot ulcers; $1.5=$ hemorrhagic streaks; $2.0=$ ulcers $>3$ but $\leq 5 ; 3.0=$ ulcers $>5$.

\subsection{Statistical Analysis}

Experimental data are expressed as mean. Statistical difference between the treated group and the control group was evaluated by one way analysis of variance (ANOVA) followed by Turkey's test as a post ANOVA (Graph Pad Prism 5, San Diego, CA, USA) to determine the statistical significance. The results were considered statistically significant with $p<0.05$. 


\section{Conclusions}

The present study was intended to isolate and characterize the newer compounds i.e., SA-1 and SA-4 in Swertia alata. The isolated compounds were characterized and investigated for their anti-inflammatory and ulcerogenic properties. The findings of the current study concludes that among the two phytoisolates of Swertia alata, the compound SA-4 possess high anti-inflammatory potential and offers less ulcerogenic and less gastric irritant effect. The current study recommends that in the future histopathological examination and further metabolic studies should be done at a molecular level to support the molecular mechanism of action of phytoisolates of Swertia alata in the in vivo models.

Author Contributions: Conceptualization, S.B., N.K.F. and S.F.; methodology, S.B.; resources, S.B., N.K.F., S.F., V.S., D.U.M., S.W., A.K., H.B., S.M. and S.K.; data curation, S.B., N.K.F., S.F., V.S., D.U.M., S.W., A.K., H.B., S.M. and S.K.; writing-original draft preparation, S.B., N.K.F. and S.F.; writingreview and editing, S.B., N.K.F., S.F., V.S., D.U.M., S.W., A.K., H.B., S.M. and S.K. All authors have read and agreed to the published version of the manuscript.

Funding: This research received no external funding.

Data Availability Statement: The data presented in this study are available in the article.

Acknowledgments: All the authors of this manuscript are thankful to their respective Departments/Universities for successful completion of this study.

Conflicts of Interest: The authors declare no conflict of interest.

\section{References}

1. Singh Jalal, J.; Jayanthi, J. An Annotated Checklist of the Orchids of Western Himalaya, India. Lankesteriana 2015, 15, 7-50.

2. Mehta, A.; Rana, R.C.; Sharma, Y.P.; Thakur, P. Physico-Chemical Analysis of Some Temperate Himalayan Swertia Species. J. Pharmacogn. Phytochem. 2018, 7, 156-159.

3. Negi, J.S.; Singh, P.; Rawat, B. Chemical Constituents and Biological Importance of Swertia: A Review. Curr. Res. Chem. 2011, 3, 1-15. [CrossRef]

4. Pant, N.; Jain, D.C.; Bhakuni, R.S. Phytochemicals from Genus Swertia and Their Biological Activities. Indian J. Chem. B 2000, 39, $565-586$.

5. Brahmachari, G.; Mondal, S.; Gangopadhyay, A.; Gorai, D.; Mukhopadhyay, B.; Saha, S.; Brahmachari, A.K. Swertia (Gentianaceae): Chemical and Pharmacological Aspects. Chem. Biodivers. 2004, 1, 1627-1651. [CrossRef] [PubMed]

6. Khetwal, S.; Pande, S.; Tiwari, U. Xanthones from Swertia alata. Indian J. Pharm. Sci. 1997, 59, 190-191.

7. Bajpai, M.B.; Asthana, R.K.; Sharma, N.K.; Chatterjee, S.K.; Mukherjee, S.K. Hypoglycemic Effect of Swerchirin from the Hexane Fraction of Swertia chirayita. Planta Med. 1991, 57, 102-104. [CrossRef]

8. Karan, M.; Bhatnagar, S.; Wangtak, P.; Vasisht, K. Phytochemical and Antimalarial Studies on Swertia alata Royle. Acta Hortic. 2005, 675, 139-145. [CrossRef]

9. Laine, L. Approaches to Nonsteroidal Anti-Inflammatory Drug Use in the High-Risk Patient. Gastroenterology 2001, 120, 594-606. [CrossRef]

10. Vane, J.R.; Botting, R.M. New Insights into the Mode of Action of Anti-Inflammatory Drugs. Inflamm. Res. 1995, 44, 1-10. [CrossRef] [PubMed]

11. Perretti, M.; D'Acquisto, F. Annexin A1 and Glucocorticoids as Effectors of the Resolution of Inflammation. Nat. Rev. Immunol. 2009, 9, 62-70. [CrossRef]

12. Smith, W.L.; DeWitt, D.L.; Garavito, R.M. Cyclooxygenases: Structural, Cellular, and Molecular Biology. Annu. Rev. Biochem. 2000, 69, 145-182. [CrossRef]

13. Ofman, J.J.; MacLean, C.H.; Straus, W.L.; Morton, S.C.; Berger, M.L.; Roth, E.A.; Shekelle, P. A Metaanalysis of Severe Upper Gastrointestinal Complications of Nonsteroidal Antiinflammatory Drugs. J. Rheumatol. 2002, 29, 804-812. [PubMed]

14. Mamdani, M.; Rochon, P.; Juurlink, D.N.; Anderson, G.M.; Kopp, A.; Naglie, G.; Austin, P.C.; Laupacis, A. Effect of Selective Cyclooxygenase 2 Inhibitors and Naproxen on Short-Term Risk of Acute Myocardial Infarction in the Elderly. Arch. Intern. Med. 2003, 163, 481-486. [CrossRef]

15. Bandgar, B.P.; Kinkar, S.N.; Chavan, H.V.; Jalde, S.S.; Shaikh, R.U.; Gacche, R.N. Synthesis and Biological Evaluation of Asymmetric Indole Curcumin Analogs as Potential Anti-Inflammatory and Antioxidant Agents. J. Enzym. Inhib. Med. Chem. 2014, 29, 7-11. [CrossRef] [PubMed]

16. Bajaj, S.; Wakode, S.; Kaur, A.; Fuloria, S.; Fuloria, N. Anti-inflammatory and ulcerogenic activity of newer phytoisolates of Swertia alata CB Clarke. Nat. Prod. Res. 2020, 2020. [CrossRef]

17. Bindu, T.K.; Shafi, P.M. Chemical Investigation of Uvaria narum Leaves. Asian J. Chem. 1998, 10, 1054.

18. Fuloria, N.K.; Fuloria, S.F. Spectroscopy: Fundamentals and Data Interpretation, 1st ed.; Studium Press: New Delhi, India, 2013. 
19. Senthilkumar, P.K.; Reetha, D. Isolation and Identification of Antibacterial Compound from the Leaves of Cassia auriculata. Eur. Rev. Med. Pharmacol. Sci. 2011, 15, 1034-1038.

20. Blobaum, A.L.; Marnett, L.J. Structural and Functional Basis of Cyclooxygenase Inhibition. J. Med. Chem. 2007, 50, 1425-1441. [CrossRef]

21. Yang, L.; Jiang, S.-T.; Zhou, Q.-G.; Zhong, G.-Y.; He, J.-W. Chemical Constituents from the Flower of Hosta Plantaginea with Cyclooxygenases Inhibition and Antioxidant Activities and Their Chemotaxonomic Significance. Molecules 2017, $22,1825$. [CrossRef]

22. Crunkhorn, P.; Meacock, S.C.R. Mediators of the Inflammation Induced in the Rat Paw by Carrageenin. Br. J. Pharmacol. 1971, 42, 392-402. [CrossRef]

23. Vetriselvan, S.; Velmurugan, P. Potential anti-inflammatory activity of Plumbago zeylanica. Asian J. Pharm. Clin. 2017, 10, 372-375.

24. Yong, Y.K.; Sulaiman, N.; Hakim, M.N.; Lian, G.E.C.; Zakaria, Z.A.; Othman, F.; Ahmad, Z. Suppressions of serotonin-induced increased vascular permeability and leukocyte infiltration by Bixa orellana leaf extract. BioMed Res. Int. 2013, 2013. [CrossRef]

25. Brattsand, R.; Thalén, A.; Roempke, K.; Källström, L.; Gruvstad, E. Influence of 16 $\alpha, 17 \alpha$-Acetal Substitution and Steroid Nucleus Fluorination on the Topical to Systemic Activity Ratio of Glucocorticoids. J. Steroid Biochem. 1982, 16, 779-786. [CrossRef]

26. Wallace, J.M. Nutritional and Botanical Modulation of the Inflammatory Cascade-Eicosanoids, Cyclooxygenases, and Lipoxygenases-As an Adjunct in Cancer Therapy. Integr. Cancer Ther. 2002, 1, 7-37. [PubMed]

27. Neto, A.G.; Costa, J.; Belati, C.C.; Vinholis, A.H.C.; Possebom, L.S.; Da Silva Filho, A.A.; Cunha, W.R.; Carvalho, J.C.T.; Bastos, J.K.; e Silva, M.L.A. Analgesic and Anti-Inflammatory Activity of a Crude Root Extract of Pfaffia glomerata (Spreng) Pedersen. J. Ethnopharmacol. 2005, 96, 87-91. [CrossRef] [PubMed]

28. Bastos, J.K.; Carvalho, J.C.; de Souza, G.H.; Pedrazzi, A.H.; Sarti, S.J. Anti-Inflammatory Activity of Cubebin, a Lignan from the Leaves of Zanthoxyllum naranjillo Griseb. J. Ethnopharmacol. 2001, 75, 279-282. [CrossRef]

29. Laavola, M.; Haavikko, R.; Hämäläinen, M.; Leppänen, T.; Nieminen, R.; Alakurtti, S.; Moreira, V.M.; Yli-Kauhaluoma, J.; Moilanen, E. Betulin Derivatives Effectively Suppress Inflammation in Vitro and in Vivo. J. Nat. Prod. 2016, 79, 274-280. [CrossRef]

30. Khanal, S.; Shakya, N.; Thapa, K.; Pant, D.R. Phytochemical investigation of crude methanol extracts of different species of Swertia from Nepal. BMC Res. Notes 2015, 8, 821. [CrossRef]

31. Kshirsagar, P.; Chavan, J.; Nimbalkar, M.; Yadav, S.; Dixit, G.; Gaikwad, N. Phytochemical composition, antioxidant activity and HPLC profiles of Swertia species from Western Ghats. Nat. Prod. Res. 2015, 29, 780-784. [CrossRef]

32. Sakshi, B.; Sharad, W. Comparative in Vitro antioxidant, anti-inflammatory and anti diabetic activity of standardized polar extracts of S. alata. MOJ Drug Des. Dev. Ther. 2018, 2, 150-154. [CrossRef]

33. Bindu, S.; Mazumder, S.; Bandyopadhyay, U. Non-steroidal anti-inflammatory drugs (NSAIDs) and organ damage: A current perspective. Biochem. Pharmacol. 2020, 180, 114147. [CrossRef] [PubMed]

34. Goltsov, A.; Swat, M.; Peskov, K.; Kosinsky, Y. Cycle Network Model of Prostaglandin H Synthase-1. Pharmaceuticals 2020, 13, 265. [CrossRef]

35. Kumar, S.G.V.; Mishra, D.N. Analgesic, Anti-Inflammatory and Ulcerogenic Studies of Meloxicam Solid Dispersion in Rodents. Iran. J. Pharmacol. Ther. 2006, 5, 77-79.

36. Brand, S.J.; Morise, Z.; Tagerud, S.; Mazzola, L.; Granger, D.N.; Grisham, M.B. Role of the proteasome in rat indomethacin-induced gastropathy. Gastroenterology 1999, 116, 865-873. [CrossRef]

37. Prempeh, A.; Mensah-Attipoe, J. Crude aqueous extract of the root bark of Zanthoxylum xanthoxyloides inhibits white blood cells migration in acute inflammation. Ghana Med. J. 2008, 42, 117-119. [PubMed]

38. Chandran, R.; George, B.P.; Abrahamse, H. Anti-Proliferative, Analgesic and Anti-Inflammatory Properties of Syzygium mundagam Bark Methanol Extract. Molecules 2020, 25, 2900. [CrossRef]

39. Sun, K.; Song, X.; Jia, R.; Yin, Z.; Zou, Y.; Li, L.; Yin, L.; He, C.; Liang, X.; Yue, G.; et al. Evaluation of Analgesic and Anti-Inflammatory Activities of Water Extract of Galla chinensis In Vivo Models. Evid. Based Complement. Altern. Med. 2018, 2018, 6784032. [CrossRef]

40. Antonisamy, P.; Dhanasekaran, M.; Kim, H.R.; Jo, S.G.; Agastian, P.; Kwon, K.B. Anti-inflammatory and analgesic activity of ononitol monohydrate isolated from Cassia tora L. in animal models. Saudi J. Biol. Sci. 2017, 24, 1933-1938. [CrossRef]

41. Xiang, Y.; Haixia, W.; Zenggen, L.; Yanduo, T. Anti-inflammatory activity of compounds isolated from Swertia mussotii. Nat. Prod. Res. 2019, 33, 598-601. [CrossRef]

42. Dey, P.; Roy Chowdhuri, S.; Sarkar, M.P.; Chaudhuri, T.K. Evaluation of anti-inflammatory activity and standardisation of hydro-methanol extract of underground tuber of Dioscorea alata. Pharm. Biol. 2016, 54, 1474-1482. [CrossRef] [PubMed]

43. Karbab, A.; Mokhnache, K.; Ouhida, S.; Charef, N.; Djabi, F.; Arrar, L.; Mubarak, M.S. Anti-inflammatory, analgesic activity, and toxicity of Pituranthos scoparius stem extract: An ethnopharmacological study in rat and mouse models. J. Ethnopharmacol. 2020, 258, 112936. [CrossRef] [PubMed]

44. Arul, B.; Kothai, R.; Jacob, P.; Sangameswaran, B.; Sureshkumar, K. Anti-inflammatory activity of Sapindus trifoliatus Linn. J. Herb. Pharmacother. 2004, 4, 43-50. [CrossRef] [PubMed]

45. das Chagas Pereira de Andrade, F.; Mendes, A.N. Computational analysis of eugenol inhibitory activity in lipoxygenase and cyclooxygenase pathways. Sci. Rep. 2020, 10, 16204. [CrossRef] 
46. Guo, C.G.; Leung, W.K. Potential Strategies in the Prevention of Nonsteroidal Anti-inflammatory Drugs-Associated Adverse Effects in the Lower Gastrointestinal Tract. Gut Liver 2020, 14, 179-189. [CrossRef]

47. Fuloria, N.K.; Fuloria, S.; Sharma, V.K.; Ali, M.; Singh, A.; Sharma, P.K. Isolation of new diterpene from methanolic extract of Capsicum annuum Linn. fruits. Pharmacogn. Mag. 2020, 16, 730-732.

48. Herrera-Salgado, Y.; Garduno-Ramirez, M.L.; Vazquez, L.; Rios, M.Y.; Alvarez, L. Myo-Inositol-Derived Glycolipids with Anti-Inflammatory Activity from Solanum anceolatum. J. Nat. Prod. 2005, 68, 1031-1036. [CrossRef]

49. Szewczuk, L.M.; Forti, L.; Stivala, L.A.; Penning, T.M. Resveratrol is a peroxidase-mediated inactivator of COX-1 but not COX-2: A mechanistic approach to the design of COX-1 selective agents. J. Biol. Chem. 2004, 279, 22727-22737. [CrossRef]

50. Winter, C.A.; Risley, E.A.; Nuss, G.W. Carrageenin-Induced Edema in Hind Paw of the Rat as an Assay for Antiinflammatory Drugs. Proc. Soc. Exp. Biol. Med. 1962, 111, 544-547. [CrossRef] [PubMed]

51. Cioli, V.; Putzolu, S.; Rossi, V.; Barcellona, P.S.; Corradino, C. The Role of Direct Tissue Contact in the Production of Gastrointestinal Ulcers by Anti-Inflammatory Drugs in Rats. Toxicol. Appl. Pharmacol. 1979, 50, 283-289. [CrossRef] 